\title{
Evaluation of phenolic compounds and protective effects of olive (Olea europaea L.) leaf extracts on endothelial cells against hydrogen peroxide-induced toxicity
}

\author{
Hilal TORUL ${ }^{1}$ * (D), Nurgün KÜÇÜKBOYACI ${ }^{2}$ (D), Uğur TAMER ${ }^{1}$ (D) , Çimen KARASU ${ }^{3}$ * (D) \\ 1 Department of Analytical Chemistry, Faculty of Pharmacy, Gazi University, Ankara, Turkey. \\ 2 Department of Pharmacognosy, Faculty of Pharmacy, Gazi University, Ankara, Turkey. \\ 3 Department of Medical Pharmacology, Faculty of Medicine, Gazi University, Ankara, Turkey. \\ * Corresponding Authors. E-mail: hilaltorul@gazi.edu.tr (H.T.); Tel. +90-312-202 3100. Fax: +90-312-223 5018. \\ E-mail: karasu@gazi.edu.tr (C.K.); Tel. +90 3122026921.
}

Received: 11 April 2020 / Revised: 16 June 2020/ Accepted: 24 June 2020

\begin{abstract}
Olea europaea L. (Oleaceae) leaves have been used for centuries in folk medicine to treat many degenerative and inflammatory diseases including hypertension, atherosclerosis and cardiovascular disorders. The present study was aimed to quantify the phenolic compounds present in three different extracts of O. europaea leaves, and to demonstrate their protective effects on human umbilical vein endothelial cells against oxidative injury induced by $\mathrm{H}_{2} \mathrm{O}_{2}$. Oleuropein, hydroxytyrosol, quercetin, luteolin and rutin in the olive leaf extracts were quantified by using a validated HPLC-UV method. Total phenolic content was determined using the Folin-Ciocalteau assay. The MTT and dichlorofluorescein assays were conducted to measure cytotoxicity and intracellular reactive oxygen species generation, respectively. Oleuropein was the major phenolic component. Each phenolic compound $(1.0$ and $10.0 \mu \mathrm{M})$ and each extract $(10.0 \mu \mathrm{g} / \mathrm{mL})$ significantly $(\mathrm{p}<0.05)$ preserved human umbilical vein endothelial cells against $\mathrm{H}_{2} \mathrm{O}_{2-}$ induced toxicity, but olive leaf extract- 1 and luteolin seemed to be more effective in studied concentrations even in the inhibition of cellular reactive oxygen species generation $(p<0.05)$. In addition, a positive correlation was found between reactive oxygen species inhibitory activity and total phenol content versus viability protecting capacity of each olive leaf extracts. These results supply a new validated HPLC method for the effective characterization of olive leaf polyphenolic compounds and support the notion that the polyphenolic components of olive leaves are the efficient cytoprotective agents against $\mathrm{H}_{2} \mathrm{O}_{2}$-induced oxidative stress and toxicity in human umbilical vein endothelial cells.
\end{abstract}

KEYWORDS: Olea europaea; cytoprotection; HPLC; oleuropein; hydroxytyrosol; quercetin; luteolin; rutin.

\section{INTRODUCTION}

Olive tree, Olea europaea L. (Oleaceae), is one of the most important fruit trees in Mediterranean region. Olive leaf extracts contain oleuropein as the major phenolic compound together with other phenolic glycosides or esters such as secoiridoids derived from tyrosol structure, i.e. hydroxytyrosol, several flavonoids and hydroxycinnamic acid derivatives, i.e. verbascoside [1,2]. Several studies have reported that olive leaf extracts (OLExts) exert many biological activities including antihyperglycemic [3], antihypertensive [4,5], and antiatherosclerotic activities [6]. Accordingly, we demonstrated that ethanolic extracts from olive leaves have cytoprotective against $\mathrm{H}_{2} \mathrm{O}_{2-}$, cytokines- or carbonyl(4-HNE)-induced toxicity and apoptosis in insulin releasing cells $[7,8]$ and cardiomyocytes [9]. These potential health benefits of olive leaves are mostly related to polyphenols such as oleuropein, hydroxytyrosol, tyrosol, tocopherol, verbascoside, elenolic acid derivatives, caffeic, $p$-coumaric and vanillic acids as well as flavonoids (luteolin, diosmetin, rutin, luteolin-7glucoside, apigenin-7-glucoside, and diosmetin-7-glucoside) [9]. Oleuropein, which is an advanced glycation end-product inhibitor [10], has been shown to decrease intracellular ROS levels, reducing amount of oxidized proteins [11] and preventing doxorubicin-induced cardiomyopathy [12].

The aim of this study was (i) to develop and apply an alternative HPLC-UV method for the simultaneous quantification of oleuropein $(\mathrm{O})$, hydroxytyrosol $(\mathrm{H})$, quercetin $(\mathrm{Q})$, luteolin $(\mathrm{L})$ and rutin $(\mathrm{R})$ in the olive leaf extracts and (ii) to investigate the effects of the extracts and reference phytochemicals, $O, H, Q$, $\mathrm{L}$ and $\mathrm{R}$ on $\mathrm{H}_{2} \mathrm{O}_{2}$-induced toxicity in human umbilical vein endothelial cells (HUVECs).

How to cite this article: Torul H, Küçükboyacı N, Tamer U, Karasu Ç. Evaluation of phenolic compounds and protective effects of olive (Olea europaea L.) leaf extracts on endothelial cells against hydrogen peroxide-induced toxicity. J Res Pharm. 2020; 24(4): $497-507$. 


\section{RESULTS}

\subsection{Optimization of HPLC-UV analysis}

The selection of the mobile phase and an appropriate elution program are essential for separation of phenolic compounds. The properties of the mobile phase indicate the separation of the compounds. In this study, an elution system composed by acetate buffer (adjusted to pH 3.2 and included $0.05 \%$ triethylamine) and acetonitrile was chosen. The presence of acetic acid in the mobile phase suppresses the dissociation of the phenolic compounds and enhances the selectivity of the eluent. Acetonitrile is the organic solvent most used in the separation of these compounds $[13,14]$. In order to optimize the chromatographic separation of the OLExts, different gradient systems were tested. The best separation was achieved using a four-step solvent gradient as described in experimental part (Table 1). The column temperature was varied between 10 and $40^{\circ} \mathrm{C}$, and was fixed as $30^{\circ} \mathrm{C}$. The choice of the optimal flow rate was based on a compromise between separation of compounds, peak width, and column backpressure, which was obtained using $1.0 \mathrm{~mL} / \mathrm{min}$. Daidzein was used as an internal standard. Analysis of the olive leaves extracts was performed under these conditions.

Table 1. Gradient elution program used for the reversed-phase HPLC-UV.

\begin{tabular}{ccccc}
\hline & \multicolumn{2}{c}{ Eluent system } & \multicolumn{2}{c}{ UV-VIS detector tuning } \\
\hline Time (min) & \% A & \% B & Time (min) & $\lambda$ (wavelength) \\
\hline 0 & 85 & 15 & 0 & 280 \\
15 & 70 & 30 & 7 & 280 \\
20 & 90 & 10 & 8 & 254 \\
25 & 85 & 15 & 30 & 254 \\
\hline
\end{tabular}

Under the following conditions: flow rate of $1.0 \mathrm{~mL} / \mathrm{min}, 30^{\circ} \mathrm{C}$, injection volume $20.0 \mu \mathrm{L}$. A: Acetate buffer (adjusted to pH 3.2 and included 0.05\% triethylamine); B: Acetonitrile

\subsection{Method validation}

Method validation was performed in accordance to the International Conference on Harmonization $(\mathrm{ICH})$ guidelines [15]. For the validation of the developed analytical method, linear regression analysis was performed by using external calibration curves. A linear response was obtained for $\mathrm{H}, \mathrm{L}, \mathrm{R}, \mathrm{O}$, and $\mathrm{Q}$. The maximum wavelength for detection was $280 \mathrm{~nm}$ for $\mathrm{H}$, and $254 \mathrm{~nm}$ for $\mathrm{L}, \mathrm{R}, \mathrm{O}$, and $\mathrm{Q}$ at which good detector response was obtained. The calibration curves were obtained in the range of $1.14-114.00 \mu \mathrm{g} / \mathrm{mL}$ for $\mathrm{H}$, and $1.10-110.00 \mu \mathrm{g} / \mathrm{mL}$ for $\mathrm{L}$, and 1.12-112.00 $\mathrm{\mu g} / \mathrm{mL}$ for $\mathrm{R}$ and $1.06-106.00 \mu \mathrm{g} / \mathrm{mL}$ for $\mathrm{O}$ and $\mathrm{Q}$, and showed excellent linearity, with $\mathrm{r}$ values of 0.993 for $\mathrm{H}, 0.994$ for $\mathrm{L}, 0.992$ for $\mathrm{R}, 0.991$ for $\mathrm{O}$, and 0.996 for $\mathrm{Q}$. The experimentally determined values of LOD and LOQ were given in (Table 2). The LOD values were found to be $0.13 \mu \mathrm{g} / \mathrm{mL}$ for $\mathrm{H}, 0.26 \mu \mathrm{g} / \mathrm{mL}$ for $\mathrm{O}, 0.04 \mu \mathrm{g} / \mathrm{mL}$ for $\mathrm{Q}, 0.11 \mu \mathrm{g} / \mathrm{mL}$ for $\mathrm{L}$, and $0.07 \mu \mathrm{g} / \mathrm{mL}$ for R. These results indicate that the developed HPLC method is sufficiently sensitive and has a good linearity for quantification of phenolic compounds present at low concentrations in extracts of olive leaves.

Table 2. Quantitative parameters and statistical data for HPLC-UV determination of phenolic compounds.

\begin{tabular}{lccccc}
\hline Compounds & Regression equation & $r$ & $\begin{array}{c}\text { Linear range } \\
(\mu \mathrm{g} / \mathrm{mL})\end{array}$ & $\begin{array}{c}\text { LOD } \\
(\mu \mathrm{g} / \mathrm{mL})\end{array}$ & $\begin{array}{c}\text { LOQ } \\
(\mu \mathrm{g} / \mathrm{mL})\end{array}$ \\
\hline Hydroxytyrosol & $\mathrm{y}=0.0137 \mathrm{x}+0.0134$ & 0.993 & $1.14-114.00$ & 0.13 & 0.42 \\
Rutin & $\mathrm{y}=0.0235 \mathrm{x}+0.0281$ & 0.992 & $1.12-112.00$ & 0.07 & 0.25 \\
Oleuropein & $\mathrm{y}=0.0068 \mathrm{x}+0.0163$ & 0.991 & $1.06-106.00$ & 0.26 & 0.85 \\
Quercetin & $\mathrm{y}=0.0424 \mathrm{x}+0.0047$ & 0.996 & $1.06-106.00$ & 0.04 & 0.14 \\
Luteolin & $\mathrm{y}=0.0487 \mathrm{x}-0.0019$ & 0.994 & $1.10-110.00$ & 0.11 & 0.36 \\
\hline
\end{tabular}

LOD: limit of detection; LOQ: limit of quantification

The precision of the developed method was checked by method repeatability (intra-day precision) and intermediate precision (inter-day precision). For the intra-day precision, the extracts of olive leaves were 
analyzed six times within a day, while for the inter-day precision they were examined in six times on two separate days. The relative standard deviation (RSD) of the peak area was calculated as measure of precision. The intra-day variability study was carried out by the injection of the same extracts of olive leaves six consecutive times within a day. The inter-day variability study was carried out by the injection of the same samples six times for two successive days using the same solution. According to the experimental results obtained, the developed method was found to be precise, with low values of intra-and inter-day variations (RSD $\leq 5 \%$ ). The results were given in Table 3. The validation data of the developed HPLC method provides good linearity and precision. Thus, the developed method was found suitable for the determination of investigated five phenolic compounds in olive leaves.

Table 3. The results of intra-and inter-day variability for phenolic compounds in olive leaves by HPLC-UV analysis.

\begin{tabular}{|c|c|c|c|c|c|c|c|c|c|c|c|c|}
\hline \multirow{3}{*}{ Compounds } & \multicolumn{6}{|c|}{ Intra-day precision $(n=6)$} & \multicolumn{6}{|c|}{ Inter-day precision $(n=6)$} \\
\hline & Ext1 & & Ext2 & & Ext3 & & Ext1 & & Ext2 & & Ext3 & \\
\hline & $\overline{\mathbf{x}}(\mathrm{mg} / \mathrm{g})$ & RSD & $\overline{\mathbf{x}}(\mathrm{mg} / \mathrm{g})$ & RSD & $\overline{\mathbf{x}}(\mathbf{m g} / \mathrm{g})$ & RSD & $\overline{\mathbf{x}}(\mathrm{mg} / \mathrm{g})$ & RSD & $\overline{\mathbf{x}}(\mathrm{mg} / \mathrm{g})$ & RSD & $\overline{\mathbf{x}}(\mathrm{mg} / \mathrm{g})$ & RSD \\
\hline Hydroxytyrosol & $1.97 \pm 0.08$ & 4.24 & $6.62 \pm 0.30$ & 4.49 & $1.43 \pm 0.04$ & 2.65 & $1.98 \pm 0.10$ & 4.85 & $6.69 \pm 0.24$ & 3.64 & $1.45 \pm 0.04$ & 2.80 \\
\hline Rutin & - & - & $0.77 \pm 0.04$ & 4.96 & $0.84 \pm 0.04$ & 4.91 & - & - & $0.77 \pm 0.03$ & 4.33 & $0.85 \pm 0.03$ & 3.45 \\
\hline Oleuropein & $216.61 \pm 2.45$ & 1.13 & $154.71 \pm 0.92$ & 0.59 & $74.54 \pm 1.36$ & 1.83 & $217.84 \pm 4.66$ & 2.14 & $154.47 \pm 1.02$ & 0.66 & $74.90 \pm 1.10$ & 1.47 \\
\hline Quercetin & $0.10 \pm 0.01$ & 4.90 & $0.88 \pm 0.03$ & 3.71 & $0.19 \pm 0.01$ & 4.60 & $0.10 \pm 0.01$ & 4.56 & $0.87 \pm 0.04$ & 4.45 & $0.19 \pm 0.01$ & 5.42 \\
\hline Luteolin & $0.38 \pm 0.01$ & 3.48 & $2.17 \pm 0.04$ & 1.91 & - & - & $0.38 \pm 0.01$ & 3.16 & $2.17 \pm 0.05$ & 2.07 & - & - \\
\hline
\end{tabular}

$\overline{\mathrm{x}}$ : Mean, RSD: relative standard deviation (\%)

\subsection{Phenolic compounds determination}

The total phenolic content, determined by Folin-Ciocalteau assay, was $15.7 \%$ for OLExt-1, $10.2 \%$ for OLExt-2, and $8.9 \%$ for OLExt-3 (gallic acid equivalent of extract).

The HPLC-UV method described above was applied to the quantification of some phenolic compounds in olive leaves from three different extracts. Figure 1 shows the molecular structures of phenolic compounds in OLExts as hydroxytyrosol $(\mathrm{H})$, oleuropein $(\mathrm{O})$, quercetin $(\mathrm{Q})$, luteolin $(\mathrm{L})$, and rutin $(\mathrm{R})$. The elution order was $\mathrm{H}$ (retention time, $4.78 \mathrm{~min}), \mathrm{R}(9.38 \mathrm{~min}), \mathrm{O}(15.67 \mathrm{~min})$, IS (daidzein, $18.13 \mathrm{~min}), \mathrm{Q}(19.81 \mathrm{~min})$ and $\mathrm{L}$ (20.30 $\mathrm{min}$ ) as shown in Figure 2. The HPLC-UV chromatogram of olive leaf extracts, OLExt-1 (A), OLExt-2 (B), and OLExt-3 (C) are shown in Figure 3. We identified several key differences among the three different olive leaf extracts, using the above method to investigate the abundance of five phenolic compounds. Phenolic composition of the olive leaf extracts $(\mathrm{mg} / \mathrm{g}$ ) is given in Table 4 . Rutin was not detected in OLExt- 1 and luteolin was not detected in OLExt-3. Oleuropein was recognized as the major compound in all the investigated extracts.

\subsection{Cytotoxicity and ROS generation}

Following incubation of endothelial cells with oxidant $\mathrm{H}_{2} \mathrm{O}_{2}$ resulted in inhibited endothelial cell viability (Figure 4) and concomitantly increased intracellular ROS levels (Figure 5). All OLExts significantly decreased $\mathrm{H}_{2} \mathrm{O}_{2}$-induced toxicity in HUVECs, however the pretreatment of HUVECs with OLExt-1 (10 $\mu \mathrm{g} / \mathrm{mL}$ ) for $12 \mathrm{~h}$ offered the greatest protection against the toxic effects of $\mathrm{H} 2 \mathrm{O} 2$ (MTT test) in comparison with OLExt-2 or OLExt-3 (Figure 4). OLExts significantly but not completely inhibited ROS formation (2',7'dichlorodihydrofluorescein diacetate $\left[\mathrm{H}_{2}\right.$ DCFDA]) in $\mathrm{H}_{2} \mathrm{O}_{2}$ exposed HUVECs. The effectiveness on ROS reduction was higher in OLExt-1 than OLExt-2 and OLExt-3, respectively (Figure 5). 
<smiles>OCCc1ccc(O)c(O)c1</smiles>

Hydroxytyrosol (H)

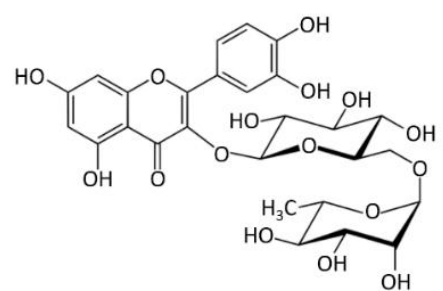

Rutin (R)<smiles></smiles>

Quercetin (Q)<smiles>C/C=C1/[C@@H](O[C@@H]2O[C@H](CO)[C@@H](O)[C@H](O)[C@H]2O)OC[C@H](C(=O)OC)[C@H]1CC(=O)OCCc1ccc(O)c(O)c1</smiles>

Figure 1. Structures of investigated phenolic compounds in olive leaves.

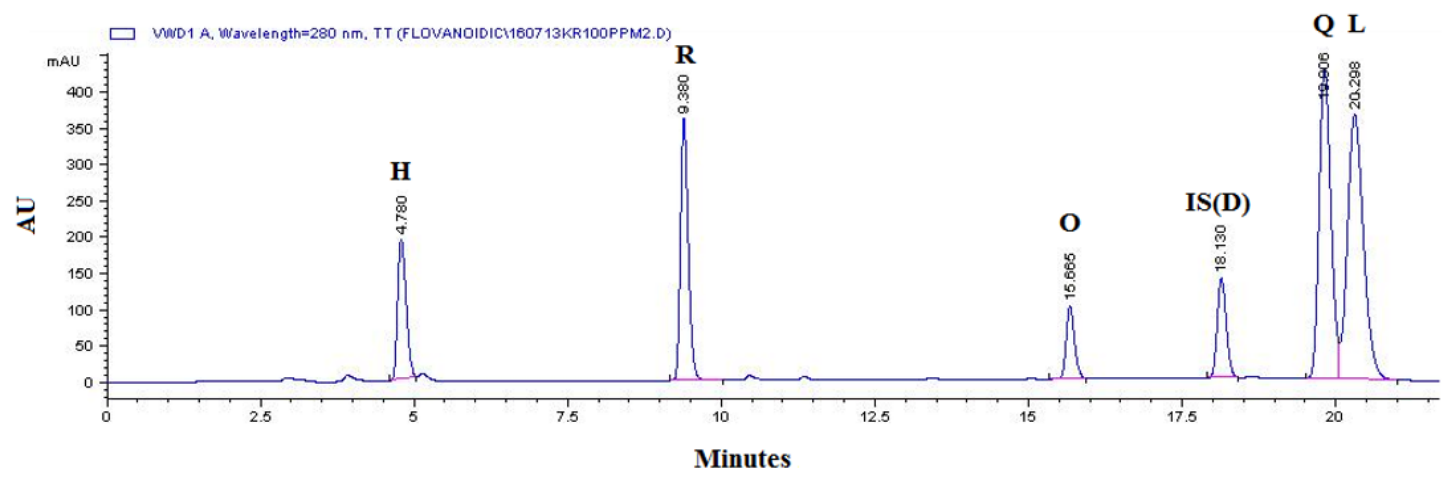

Figure 2. The HPLC-UV chromatogram of hydroxytyrosol $(\mathrm{H})$, rutin $(\mathrm{R})$, oleuropein $(\mathrm{O})$, quercetin $(\mathrm{Q})$, luteolin (L).

The pretreatment of HUVECs with the reference phenolic compounds, $\mathrm{O}, \mathrm{H}, \mathrm{Q}, \mathrm{L}$, or R $(1.0-10.0 \mu \mathrm{mol} / \mathrm{L})$ led to different degrees protection on the viability against $\mathrm{H}_{2} \mathrm{O}_{2}$ induced toxicity (Figure 4). Reference compounds (at 1.0 and $10.0 \mu \mathrm{mol} / \mathrm{L}$ concentrations) and OLExts all failed to provide complete protection on HUVECs. However, L had the greatest effects on preserving viability and inhibiting ROS production in cells exposed to $\mathrm{H}_{2} \mathrm{O}_{2}$. OLExt-1 had a major peak coincident with the elution time expected for O; the concentration of this compound relative to other peaks distinguished OLExt-1 from the other extracts. $\mathrm{R}$ and $\mathrm{Q}$ were not detected in OLExt-1 (Table 4). The peak area at the same elution time as L was greater in OLExt-2 than OLExt1. Thus, the effectiveness of OLExt- 1 as stress protectant is unlikely to be attributable to $Q$, R, or L, however the mixture of compounds prepared in this extraction method may be important.

Table 4. Phenolic compounds of the three different extracts (OLExt-1, OLExt-2, OLExt-3) of olive leaves $(\mathrm{mg} / \mathrm{g})$

\begin{tabular}{llllll}
\hline Samples & $\begin{array}{c}\text { Hydroxytyrosol } \\
\left(t_{R}: 4.66 \mathrm{~min}\right)\end{array}$ & $\begin{array}{c}\text { Rutin } \\
\left(t_{R}: 9.32 \mathrm{~min}\right)\end{array}$ & $\begin{array}{c}\text { Oleuropein } \\
\left(t_{R}: 15.42 \mathrm{~min}\right)\end{array}$ & $\begin{array}{c}\text { Quercetin } \\
\left(t_{R}: 19.72 \mathrm{~min}\right)\end{array}$ & $\begin{array}{c}\text { Luteolin } \\
\left(t_{R}: 20.17 \mathrm{~min}\right)\end{array}$ \\
\hline OLExt-1 & $1.97 \pm 0.08$ & $\mathrm{nd}$ & $216.61 \pm 2.45$ & $0.10 \pm 0.01$ & $0.38 \pm 0.01$ \\
OLExt-2 & $6.62 \pm 0.30^{* *}$ & $0.77 \pm 0.04$ & $154.71 \pm 0.92^{* *}$ & $0.88 \pm 0.03$ & $2.17 \pm 0.04^{* *}$ \\
OLExt-3 & $1.43 \pm 0.04^{*}$ & $0.84 \pm 0.04$ & $74.54 \pm 1.36^{* *}$ & $0.19 \pm 0.01$ & $\mathrm{nd}$ \\
\hline
\end{tabular}

${ }^{*} P<0.05,{ }^{* *} P<0.01$, vs OLExt-1. nd: not detected 


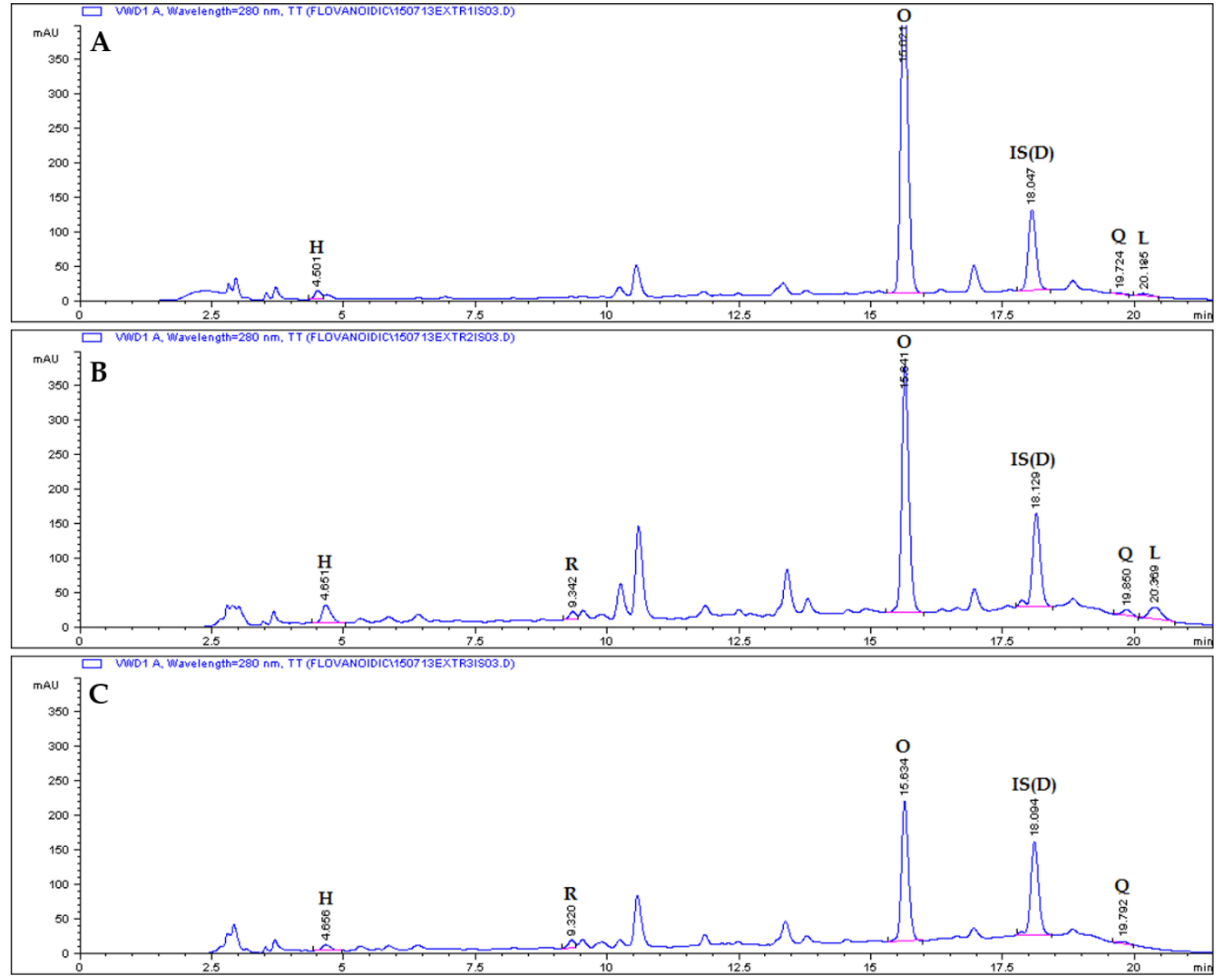

Figure 3. The HPLC-UV chromatogram of olive leaf extracts, OLExt-1 (A), OLExt-2 (B) and OLExt-3 (C). Hydroxytyrosol $(\mathrm{H})$, rutin $(\mathrm{R})$, oleuropein $(\mathrm{O})$, quercetin(Q), luteolin $(\mathrm{L})$

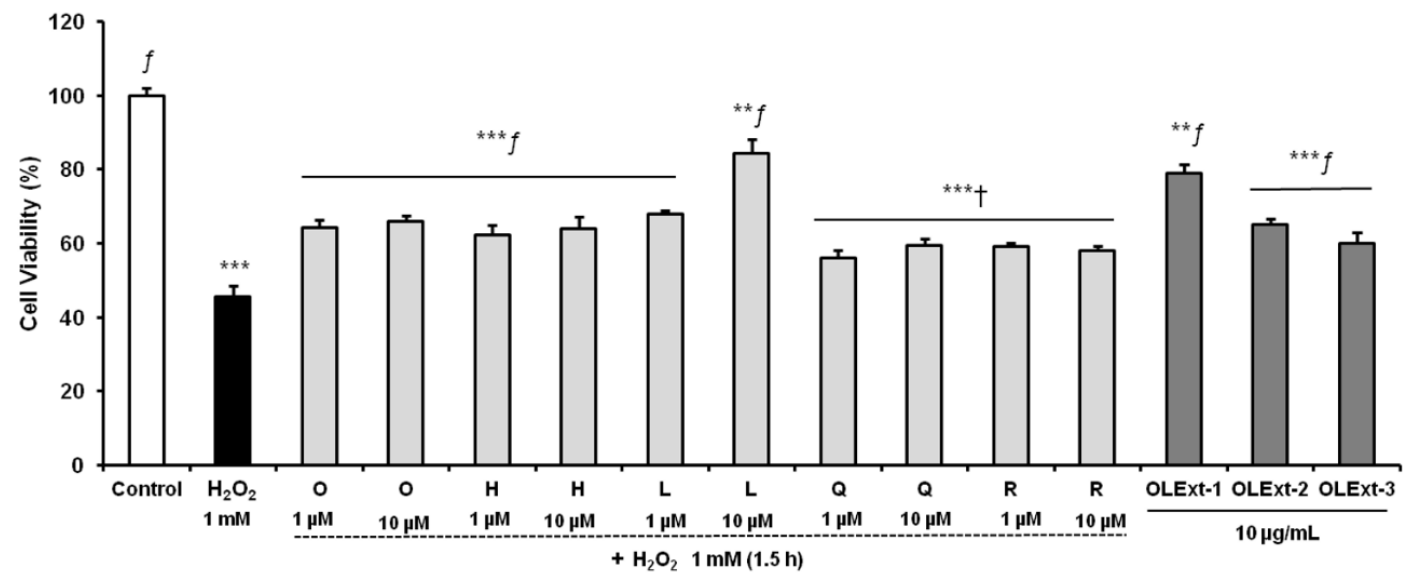

Figure 4. Effect of phenolic compounds (O: oleuropein; H: hydroxytyrosol; L: luteolin; Q: quercetin; R: rutin) and the extracts (OLExt-1, OLExt-2, OLExt-3) of olive leaves on HUVECs viability in response to $\mathrm{H}_{2} \mathrm{O}_{2}$. The cells were pre-incubated with each phytochemical or OLExts for $12 \mathrm{~h}$ and then exposed to $\mathrm{H}_{2} \mathrm{O}_{2}(1.0 \mathrm{mM})$ for $1,5 \mathrm{~h}$. The cell viability was determined by the MTT assay. All data are expressed as the means \pm SD (n $\left.\left.=6) .{ }^{* *}\right) \mathrm{p}<0.01,{ }^{* * *}\right) \mathrm{p}<0.001$ vs Control; $(\mathrm{t}) \mathrm{p}<0.01,(f) \mathrm{p}<0.001$ vs $\mathrm{H}_{2} \mathrm{O}_{2}$. 


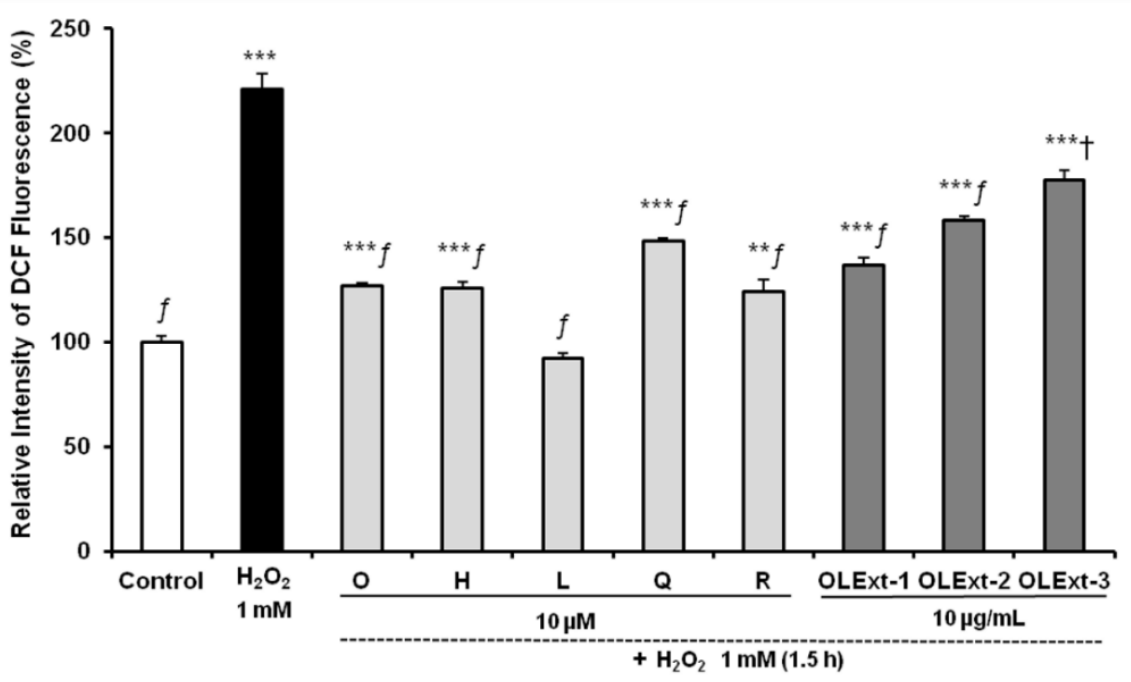

Figure 5. Comparison of the inhibitory activities of phenolic compounds (O: oleuropein; H: hydroxytyrosol; L: luteolin; Q: quercetin; R: rutin) and the extracts (OLExt-1, OLExt-2, OLExt-3) of olive leaves on ROS generation induced by $\mathrm{H}_{2} \mathrm{O}_{2}$ in HUVEC cultures. The cells were pre-incubated with protective concentration of each phenolic compounds $(10.0 \mu \mathrm{M})$ or the extracts $(10.0 \mu \mathrm{g} / \mathrm{mL})$ for $30 \mathrm{~min}$ and then exposed to $\mathrm{H}_{2} \mathrm{O}_{2}$ $(1.0 \mathrm{mM})$ for $1,5 \mathrm{~h}$. ROS generation was determined by the DCF assay. All data are expressed as the means $\pm \mathrm{SD}(\mathrm{n}=6) .\left(^{* *}\right) \mathrm{p}<0.01,\left({ }^{* * *}\right) \mathrm{p}<0.001$ vs Control; $(\dagger) \mathrm{p}<0.01,(f) \mathrm{p}<0.001$ vs $\mathrm{H}_{2} \mathrm{O}_{2}$.

\section{DISCUSSION}

We developed an alternative HPLC-UV method for the quantification of oleuropein, hydroxytyrosol, quercetin, luteolin and rutin, and evaluated the total phenolic content by Folin-Ciocalteu method using gallic acid as standard in three different olive leaf extracts. Furthermore, the protective effects of the extracts on $\mathrm{H}_{2} \mathrm{O}_{2}$-induced toxicity in human umbilical vein endothelial cells was investigated.

Several studies have been reported in literature regarding the use of HPLC systems for determination of the phenolic compounds in the olive leaf extracts. We compared our method with the other HPLC methods in terms of amounts of phenolic compounds. In the present study, the amounts of oleuropein as the major compound were found as 216.6, 154.7, and $74.5 \mathrm{mg} / \mathrm{g}$ in OLExt-1, OLExt-2, and OLExt-3, respectively. Xie and co-workers [16] were reported an HPLC-UV method for determination of ten phenolic compounds in both olive leaf extract (OLE), and olive fruit extract (OFE). Oleuropein $(6.53 \mathrm{mg} / \mathrm{g})$ was found as the main compound in OLE. This report indicated that the OLE contained trace amounts of the other phenolic compounds. The amounts of hydroxytyrosol, rutin, and luteolin were found less than $0.6 \mathrm{mg} / \mathrm{g}$. An HPLCDAD-TOF-MS technique was reported for the determination of several phenolic compounds in extracts of three olive leaf cultivars [17]. They also revealed that oleuropein $(66.4,35.66$, and $41.7 \mathrm{mg} / \mathrm{g}$ in three samples) was the major compound for all olive leaf cultivars. The amounts of hydroxytyrosol, luteolin and rutin were found less than $2.0 \mathrm{mg} / \mathrm{g}$. In another report, they analyzed the olive leaf samples extracted with different solvents ( $80 \%$ ethanol, $20 \%$ acetonitrile, and distilled water) by using an HPLC-UV method [18]. For the sample extracted with $80 \%$ ethanol, oleuropein $(29.5 \mathrm{mg} / \mathrm{g}$ ) was found the major compound. Rutin, luteolin, hydroxytyrosol, and quercetin were presented as the minor phenolic compounds. The results obtained from the developed study are consistent with the literature. Besides, we compared the results of the total phenolic content of the investigated extracts with each other and 70\% ethanol extract (OLExt-1) of the plant was found to be rich in phenolic compounds than the other extracts.

Olive leaves are a rich source of phenolic compounds, and OLExts are now popular as nutraceutical, taken either as liquid or capsules to treat blood pressure and atherosclerosis $[2,4,6,19,20]$. Recently, olive leaf has been reported as an anti-inflammatory, antioxidant, antithrombotic and antidiabetic agent $[2,19,21,22]$. In another report, the usage of olive leaves was emphasized as an antioxidant source in pharmaceuticals [23]. Ghomari and co-workers worked on antibacterial activities of phenolic compounds against pathogenic bacteria and demonstrated that oleuropein showed a strong antibacterial activity [18]. It has been demonstrated that olive phenolic compounds, especially oleuropein or hydroxytyrosol exhibit L-type $\mathrm{Ca}^{2+}$ channel antagonistic effects [24] and protect against vascular risk through the down-regulation of adhesion molecules $[25,26]$. 
We previously showed that olive leaf phenolic compounds and extracts protect cardiomyocytes against carbonyl-induced stress, inhibit stress activated transcription factors and ameliorate mitochondrial functions in H9c2 cell culture [9]. Although the mechanisms of athero-protective and cardio-protective effects of olive oil or fruit were widely studied, the endothelium protecting effect of olive leaf polyphenolic extracts have been among the first to be demonstrated. Since physiological functions of endothelium influence vaso-reactivity, blood pressure and cardiovascular health, in the present study we evaluated the effects of polyphenolic contents of OLExts on human HUVECs. We found that all OLExts significantly decreased $\mathrm{H}_{2} \mathrm{O}_{2}$-induced toxicity in HUVECs. In comparison with OLExt-2 or OLExt-3, the pretreatment of HUVECs with OLExt-1 provided the greatest protection against the toxic effects of $\mathrm{H}_{2} \mathrm{O}_{2}$ and greatest inhibition of intracellular ROS formation. These results support previous findings which showed a protective role of olive leaf against diabetes induced risks through the inhibition of $\mathrm{H}_{2} \mathrm{O}_{2}$ and cytokines-induced toxicity in pancreatic $\beta$-cell cultures $[7,8]$.

In this research, the function of olive leaf phenolic compounds in protecting human HUVEC cells against $\mathrm{H}_{2} \mathrm{O}_{2}$ induced cell viability and ROS production was investigated. Although the mechanism by which underlies the effect of olive leaf phenolic compounds in protecting human HUVEC cells against $\mathrm{H}_{2} \mathrm{O}_{2}$-induced toxicity will be examined in future study, previously it has been demonstrated that olive leaf phenolic compounds inhibit $\mathrm{H}_{2} \mathrm{O}_{2}$-induced P38 and JNK phosphorylation but enhanced ERK1/2 phosphorylation, ameliorate endogenous antioxidant defence and reduce oxidative post-translational protein modifications in different cell cultures [27-29].

\section{CONCLUSION}

This study quantified the phenolic compounds of oleuropein, hydroxytyrosol, quercetin, luteolin and rutin in three different extracts (OLExts) of olive leaves, and evaluated the protective effect of OLExts, $\mathrm{O}, \mathrm{H}$, $\mathrm{Q}$, $\mathrm{L}$ and $\mathrm{R}$ against $\mathrm{H}_{2} \mathrm{O}_{2}$-induced toxicity in endothelial cells (HUVECs). The validation results indicate that the method is suitable for quantification of the five investigated phenolic compounds in olive leaves. The gradient HPLC method described in this study allowed rapid separation and identification of $H, R, O, Q$, and L. This method could be used for the routine analysis of olive leaf extracts. This study suggests that OLExts effectively protect HUVECs against oxidant induced stress and injury via modification of ROS-related mechanism. These findings support the cardio-protecting effects of olive leaves shown in previous in vivo studies and support the continued utilization of nutraceuticals including standardized olive leaves for cardiovascular disease prevention.

\section{MATERIALS AND METHODS}

\subsection{Chemicals, reagents and cell line}

HPLC grade reagents such as methanol, ethanol, acetonitrile and acetic acid (Merck Co., Darmstadt, Germany) were used for preparing the mobile phase. Standards of hydroxytyrosol, oleuropein, quercetin and luteolin were purchased from AppliChem (Darmstadt, Germany). Rutin and daidzein, used as internal standards (IS), fetal bovine serum (FBS), hydrogen peroxide $\left(\mathrm{H}_{2} \mathrm{O}_{2}\right)$, Folin-ciocalteau reagent and gallic acid were acquired from Sigma-Aldrich Co. (LLC, St. Louis, MO, USA).

Dulbecco's modified Eagle's medium (DMEM) was obtained from Thermo Scientific (Waltham, MA, USA). Penicillin and streptomycin were obtained from Lonza (Walkersville, MD, USA). 3-(4,5dimethylthiazol-2-yl)-2,5-diphenyltetrazolium bromide (MTT) was supplied from (Merck, Co., Darmstadt, Germany). Dimethyl sulfoxide (DMSO), 2',7'-dichlorodihydrofluorescein diacetate ( $\left.\mathrm{H}_{2} \mathrm{DCFDA}\right)$ dye and Hank's balanced saline solution were purchased from Fisher Scientific Inc. (Waltham, MA, USA). Human Umbilical Vein Endothelial Cells (HUVECs) were obtained from American Type Culture Collection (Manassas, VA, USA).

\subsection{Preparation of olive leaf extracts}

Olive leaf extracts (OLExts) as OLExt-1, -2 and -3, were obtained from Farmasens Co., Ltd. (Ankara, Turkey). The OLExt-1, -2 and -3 were manufactured from the dried leaves of Olea europaea L. (Oleaceae), applying the following extraction procedure. For the extraction of phenolic compounds, $5.0 \mathrm{~g}$ from the each of the olive leaf samples was extracted with solvents $(30.0 \mathrm{~mL} \mathrm{70 \%} \mathrm{ethanol} \mathrm{for} \mathrm{OLExt-1,} 30.0 \mathrm{~mL} 80 \%$ methanol for OLExt-2, and $30.0 \mathrm{~mL} \mathrm{50 \%} \mathrm{ethanol} \mathrm{for} \mathrm{OLExt-3)} \mathrm{in} \mathrm{an} \mathrm{ultrasonic} \mathrm{bath} \mathrm{for} 30 \mathrm{~min}$. This procedure was repeated two times as a sequence treatment. After extraction, the extracts were filtered using a Buchner funnel 
and Whatman No. 1 filter paper. After filtering the collected extract samples, each filtrate was concentrated in a rotavapor under reduced pressure below $40^{\circ} \mathrm{C}$. The concentrated aqueous extracts were lyophilized to give OLExt-1, OLExt-2, and OLExt-3. For all stages in this study, a single batch of each extracts was used. Extracts were stored in sterilized microtubes, stored at room temperature, and protected from light until use.

\subsection{High performance liquid chromatography (HPLC) analysis}

\subsubsection{Instrumentation}

The HPLC system used was an Agilent Technologies (Santa Clara, CA) 1200 series with a G1311A pump, G1322A degasser, G1316A column heater, G1328B manual injector and G1314B variable wavelength detector. A $250 \mathrm{~mm} \times 4.6 \mathrm{~mm}$ ACE C-18 column (Advanced Chromatography Technologies Ltd., Aberdeen, Scotland; Part No. 121-2546) was used as the stationary phase.

\subsubsection{Chromatographic conditions}

The chromatographic separation of the phenolic compounds in the olive leaf extracts was carried out using a gradient of acetate buffer (adjusted to $\mathrm{pH} 3.2$ and included $0.05 \%$ triethylamine) (A) and acetonitrile (B), at a flow rate of $1.0 \mathrm{~mL} / \mathrm{min}$. The mobile phase was filtered through a $0.45 \mu \mathrm{m}$ nylon-membrane filter (Millipore, Barcelona, Spain) and degassed with suction prior to use. In each run, $20.0 \mu \mathrm{L}$ of sample was injected and exposed to a four-step solvent gradient starting from $85 \%$ acetate buffer changing to $70 \%$ at 15 $\mathrm{min}, 90 \%$ at $20 \mathrm{~min}, 85 \%$ at $25 \mathrm{~min}$. The detection of the phenolic compounds was accomplished with a UVVIS detector, and chromatograms were acquired at $280 \mathrm{~nm}$ from $0 \mathrm{~min}$ to $7 \mathrm{~min}$ and $254 \mathrm{~nm}$ from $8 \mathrm{~min}$ to 25 min. The column temperature was set to $30^{\circ} \mathrm{C}$, and the peak areas were recorded.

\subsubsection{Sample preparation for HPLC analysis}

The validation of the proposed HPLC method was performed by analyzing OLExt-1, OLExt-2 and OLExt-3. For HPLC analysis, $5.2 \mathrm{mg}, 4.8 \mathrm{mg}$ and $5.6 \mathrm{mg}$ of dried OLExt-1, -2, and -3 , respectively, was dissolved in $1.0 \mathrm{~mL}$ DMSO and diluted to $2.0 \mathrm{~mL}$ with methanol. Then $50.0 \mu \mathrm{L}$ of the internal standard (daidzein, $12.5 \mu \mathrm{g} / \mathrm{mL}$, prepared with methanol) was spiked into each sample. The extracts were filtered through a $0.45 \mu \mathrm{m}$ nylon-membrane filter and $20.0 \mu \mathrm{L}$ aliquots were analyzed by HPLC-UV method.

\subsubsection{Preparation of stock and standard solutions}

Individual stock solutions of hydroxytyrosol $(1.14 \mathrm{mg} / \mathrm{mL})$ and oleuropein $(1.06 \mathrm{mg} / \mathrm{mL})$ were prepared in $1.0 \mathrm{~mL}$ of deionized water and then added $4.0 \mathrm{~mL}$ of methanol to the resulting solution. Individual stock solutions of quercetin $(1.06 \mathrm{mg} / \mathrm{mL})$ and rutin $(1.12 \mathrm{mg} / \mathrm{mL})$ were prepared in $5.0 \mathrm{~mL}$ of methanol. Stock solution of luteolin $(1.10 \mathrm{mg} / \mathrm{mL})$ was prepared in $200.0 \mu \mathrm{L}$ of DMSO and $4.8 \mathrm{~mL}$ of methanol. These stock solutions were diluted 10 -fold with methanol. The prepared stock solutions were stored in dark under refrigeration at $4^{\circ} \mathrm{C}$. The standard solutions of these five compounds were prepared by diluting the stock solutions with methanol. These standard solutions were directly injected into the HPLC system. The standard solutions were prepared at six different concentrations of 1.14,5.70, $11.14,22.30,57.00$ and $114.00 \mu \mathrm{g} / \mathrm{mL}$ for hydroxytyrosol, and 1.10, 5.50, 11.00, 22.00, 55.00, and $110.00 \mu \mathrm{g} / \mathrm{mL}$ for luteolin and 1.12, 5.60, 11.20, 22.40, 56.00 , and $112.00 \mu \mathrm{g} / \mathrm{mL}$ for rutin. Besides, the standard solutions of oleuropein and quercetin were prepared at six different concentrations of $1.06,5.30,10.60,21.20,53.00$, and $106.00 \mu \mathrm{g} / \mathrm{mL}$.

\subsubsection{Method validation}

The protocol, described above, was validated by evaluating the linear range of detectability, the limit of detection (LOD), the limit of quantification (LOQ) and precision. The linear range of detectability is dependent on the compound analyzed and detector used. The calibration curves for each phenolic compound were created using the peak area values against the six different concentrations of standard solutions of $\mathrm{H}, \mathrm{L}, \mathrm{R}, \mathrm{O}$ and $Q$ in the range of 1.14-114.00 $\mu \mathrm{g} / \mathrm{mL}, 1.10-110.00 \mu \mathrm{g} / \mathrm{mL}, 1.12-112.00 \mu \mathrm{g} / \mathrm{mL}$, and 1.06-106.00 $\mu \mathrm{g} / \mathrm{mL}$ (both $\mathrm{O}$ and $\mathrm{Q})$, respectively. The calibration curves were determined from three replicate injections and the standard deviation was calculated to evaluate reproducibility.

The LOD and LOQ values were calculated from the calibration curves. LOD, which is expressed in units of concentration, describes the lowest concentration level of a compound that can be distinguished. The slope of the calibration curves $(\mathrm{b})$ and the standard error of the independent term of the regression $(\mathrm{Sb})$ were used to calculate the LOD and LOQ, following International Union of Pure and Applied Chemistry definitions [30]. 
Intra-day and inter-day variations were used to determine the precision of the developed method. For the intra-day precision, the extracts of olive leaves were analyzed six times within one day, while for the interday precision they were examined in six times on two separate days. The relative standard deviation (RSD) of the peak area was calculated as measure of precision.

\subsection{Determination of the total phenolic content}

Total phenolic content of the OLExts was determined by spectrophotometric method using the FolinCiocalteau assay [31], which is based on a colorimetric oxidation and reduction reaction. An aliquot (0.5 mL) of each extract was reacted with $1.25 \mathrm{~mL}$ of freshly prepared $20 \%$ sodium carbonate and $0.5 \mathrm{~mL}$ of $1 \mathrm{~N}$ Folin Ciocalteau's reagent in a screw-top test tube. The dilutions were prepared with distilled water. Test tubes were vortexed and after $40 \mathrm{~min}$, absorbance readings were recorded at $760 \mathrm{~nm}$ by a UV-Vis Spectrophotometer (Shimadzu, Japan). A calibration curve was constructed, using gallic acid (1.0-250.0 $\mu \mathrm{g} / \mathrm{mL})$ as the calibration standard. The regression coefficient of gallic acid was 0.9986 . The amount of total phenolic compounds was expressed as milligram of gallic acid equivalent (GAE) per gram of extract weight.

\subsection{Cell culture and viability}

HUVECs were cultured in DMEM supplemented with $10 \%$ heat-inactivated FBS, $100.0 \mathrm{U} / \mathrm{mL}$ penicillin and $100.0 \mu \mathrm{g} / \mathrm{mL}$ streptomycin in a humidified atmosphere of $5 \% \mathrm{CO}_{2}$ at $37^{\circ} \mathrm{C}$ in polylysine-coated flasks. The MTT assay, a colorimetric assay for assessing cell viability, was used in this study [32]. Oxidative stress was induced through the incubation of cells with $\mathrm{H}_{2} \mathrm{O}_{2}$. HUVECs were pretreated with each phenolic compound $(1.0 \mu \mathrm{M}$ and $10.0 \mu \mathrm{M})$ or the OLExts $(10.0 \mu \mathrm{g} / \mathrm{mL})$ for $12 \mathrm{~h}$, and then were incubated with $1.0 \mathrm{mM} \mathrm{H}_{2} \mathrm{O}_{2}$ for 1.5 $h$, as described previously [33]. After exposure to $\mathrm{H}_{2} \mathrm{O}_{2}, 20.0 \mu \mathrm{L}$ of MTT stock solution was added to each well at a final concentration of $0.5 \mathrm{mg} / \mathrm{mL}$. After $4 \mathrm{~h}$ of incubation, $100.0 \mu \mathrm{L}$ of DMSO was added to dissolve the formazan crystals, and the absorbance was read using a plate reader (Biotek Instruments Inc., Winooski, VT, USA) at a wavelength of $572 \mathrm{~nm}$.

\subsection{Measurement of reactive oxygen species (ROS) in cells}

The oxidation of 2',7'-dichlorofluorescin $\left(\mathrm{H}_{2} \mathrm{DCF}\right)$ to $2^{\prime}, 7^{\prime}$-dichlorofluorescein $(\mathrm{DCF})$ was used for the quantitation of intracellular ROS production. Cells were seeded on 96 -well plates at $2 \times 10^{4}$ cells per well. After treatment with each phenolic phytochemical $(1.0 \mu \mathrm{M}$ and $10.0 \mu \mathrm{M})$ or the extract $(10.0 \mu \mathrm{g} / \mathrm{mL})$ for $12 \mathrm{~h}$, the cells were washed twice with Hank's balanced saline solution and then incubated with $10.0 \mu \mathrm{mol} / \mathrm{L} 2^{\prime}, 7^{\prime}$ dichlorodihydrofluorescein diacetate $\left(\mathrm{H}_{2} \mathrm{DCFDA}\right)$ for one hour at $37^{\circ} \mathrm{C}$ in the dark. Oxidation of the dye by intracellular ROS generates a fluorescent DCF signal. Fluorescence was measured using the excitation/emission wavelengths 485/530 nm with a Biotek FL600 microplate reader (Biotek Instruments Inc., Winooski, VT, USA) [34].

\subsection{Statistical analysis}

All the experiments were carried out in triplicate with the data presented as mean values \pm SD. Means and standard deviations were calculated with SPSS 20.0 software (Chicago, USA). A single factor analysis of variance (ANOVA) along with the post-hoc Tukey's test was employed for statistical analysis. To verify the hypothesis about the equality of variances, Levene's test was employed. Results were considered statistically significant for $P$ values $<0.05$.

Acknowledgements: We thank to Farmasens Co., Ltd. (Ankara, Turkey) for OLExts. This work was supported by Gazi University-BAP (01/2012-70), EU-COST-BM1203 (EU-ROS) and KOSGEB (2011-0850).

Author contributions: Concept - N.K., C.K; Design - H.T., N.K., U.T., C.K.; Supervision - N.K., C.K.; Resources - N.K., U.T., C.K.; Materials - N.K., U.T., C.K.; Data Collection and/or Processing - H.T., N.K., U.T., C.K.; Analysis and/or Interpretation - H.T., N.K., U.T., C.K.; Literature Search - H.T., N.K., U.T., C.K.; Writing - H.T., N.K., U.T., C.K.; Critical Reviews - H.T., N.K., U.T., C.K.

Conflict of interest statement: The authors declared no conflict of interest.

\section{REFERENCES}

[1] Baycin D, Altiok E, S. Ulku S, Bayraktar O. Adsorption of olive leaf (Olea europaea L.) antioxidants on silk fibroin. J Agric Food Chem. 2007; 55(4): 1227-1236. [CrossRef] 
[2] Kontogianni VG, Gerothanassis IP. Phenolic compounds and antioxidant activity of olive leaf extracts. Nat Prod Res. 2012; 26(2): 186-189. [CrossRef]

[3] El-Amin M, Virk P, Elobeid MA, Almarhoon ZM, Hassan ZK, Omer SA, Merghani NM, Daghestani MH, Al-Olayan EM. Anti-diabetic effect of Murraya koenigii (L) and Olea europaea (L) leaf extracts on streptozotocin induced diabetic rats. Pak J Pharm Sci. 2013; 26, 359-365.

[4] Khayyal MT, El-Ghazaly MA, Abdallah DM, Nassar NN, Okpanyi SN, Kreuter MH. Blood pressure lowering effect of an olive leaf extract (Olea europaea) in L-NAME induced hypertension in rats. Arzneimittelforschung. 2002; 52(11): 797-802. [CrossRef]

[5] Susalit E, Agus N, Effendi I, Tjandrawinata RR, Nofiarny D, Perrinjaquet-Moccetti T, Verbruggen M. Olive (Olea europaea) leaf extract effective in patients with stage-1 hypertension: comparison with Captopril. Phytomedicine. 2011; 18(4): 251-258. [CrossRef]

[6] Wang L, Geng C, Jiang L, Gong D, Liu D, Yoshimura H, Zhong L. The anti-atherosclerotic effect of olive leaf extract is related to suppress inflammatory response in rabbits with experimental atherosclerosis. Eur J Nutr. 2008; 47(5): 235-243. [CrossRef]

[7] Cumaoglu A, Rackova L, Stefek M, Kartal M, Maechler P, Karasu C. Effects of olive leaf polyphenols against $\mathrm{H}_{2} \mathrm{O}_{2}$ toxicity in insulin secreting $\beta$-cells. Acta Biochim Pol. 2011; 58(1): 45-50.

[8] Cumaoglu A, Ari N, Kartal M, Karasu C. Polyphenolic extracts from Olea europaea L. protect against cytokine-induced $\beta$-cell damage through maintenance of redox homeostasis. Rejuvenation Res. 2011; 14(3): 325-334. [CrossRef]

[9] Bali EB, Ergin V, Rackova L, Bayraktar O, Küçükboyacı N, Karasu C. Olive leaf extracts protect cardiomyocytes against 4-HNE-induced toxicity in vitro: Comparison with oleuropein, hydroxytyrosol and quercetin. Planta Medica. 2014; 80(12): 984-992. [CrossRef]

[10] Kontogianni VG, Charisiadis P, Margianni E, Lamari FN, Gerothanassis IP, Tzakos AG. Olive leaf extracts are a natural source of advanced glycation and product inhibitors. J Med Food. 2013; 16(9): 817-822. [CrossRef]

[11] Katsiki M, Chondrogianni N, Chinou I, Rivett AJ, Gonos ES. The olive constituent oleuropein exhibits proteasome stimulatory properties in vitro and confers life span extension of human embryonic fibroblasts. Rejuvenation Res. 2007; 10(2): 157-172. [CrossRef]

[12] Andreadou I, Mikros E, Ioannidis K, Sigala F, Naka K, Kostidis S, Farmakis D, Tenta R, Kavantzas N, Bibli SI, Gikas E, Skaltsounis L, Kremastinos DT, Iliodromitis EK. Oleuropein prevents doxorubicin-induced cardiomyopathy interfering with signaling molecules and cardiomyocyte metabolism. J Mol Cell Cardiol. 2014; 69: 4-16. [CrossRef]

[13] Ryan D, Robards K, Prenzler P, Jardine D, Herlt T, Antolovich M. Liquid chromatography with electrospray ionisation mass spectrometric detection of phenolic compounds from Olea europaea. J Chromatogr A. 1999; 855(2): 529-537. [CrossRef]

[14] Blekas G, Psomiadou E, Tsimidou M, Boskou D. On the importance of total polar phenols to monitor the stability of Greek virgin olive oil. Eur J Lip Sci Tech. 2002; 104(6): 340-346. [CrossRef]

[15] ICH, Q2 (R1) Validation of analytical procedures: text and methodology, International Conference on Harmonization, IFPMA, Geneva, 2005. [CrossRef]

[16] Xie P, Huang L, Zhang C, Zhang Y. Phenolic compositions, and antioxidant performance of olive leaf and fruit (Olea europaea L.) extracts and their structure-activity relationships. J Func Food. 2015; 16: 460-471. [CrossRef]

[17] Talhaoui N, Vezza T, Gómez-Caravaca AM, Fernández-Gutiérrez A, Gálvez J, Segura-Carretero A. Phenolic compounds and in vitro immunomodulatory properties of three Andalusian olive leaf extracts. J Func Food. 2016; 22: 270-277. [CrossRef]

[18] Ghomari O, Sounni F, Massaoudi Y, GhanamJ, Kaitouni LBD, Merzouki M, Benlemlih M. Phenolic profile (HPLCUV) of olive leaves according to extraction procedure and assessment of antibacterial activity. Biotechnology Reports. 2019; 23: e00347. [CrossRef]

[19] García-Villalba R, Larrosa M, Possemiers S, Tomás-Barberán FA, Espín JC. Bioavailability of phenolics from an oleuropein-rich olive (Olea europaea) leaf extract and its acute effect on plasma antioxidant status: comparison between pre- and postmenopausal women. Eur J Nutr. 2014; 53(4): 1015-1027. [CrossRef]

[20] Abreu IC, Marinho AS, Paes AM, Freire SM, Olea RS, Borges MO, Borges AC. Hypotensive and vasorelaxant effects of ethanolic extract from Jatropha gossypiifolia L. in rats. Fitoterapia. 2003; 74(7-8): 650-657. [CrossRef]

[21] Dub AM, Dugani AM. Antithrombotic effect of repeated doses of the ethanolic extract of local olive (Olea europaea L.) leaves in rabbits. Libyan J Med. 2013; 8(1): 20947. [CrossRef] 
[22] Liu YN, Jung JH, Park H, Kim H. Olive leaf extract suppresses messenger RNA expression of proinflammatory cytokines and enhances insulin receptor substrate 1 expression in the rats with streptozotocin and high-fat dietinduced diabetes. Nutr Res. 2014; 34(5): 450-457. [CrossRef]

[23] Kabbasha EM, Ayoubb IM, Abdel-Shakoura ZT, El-Ahmadyb SH. A Phytochemical study on Olea europaea L. olive leaf extract (cv. Koroneiki) growing in Egypt. Arch Pharm Sci ASU. 2019; 3(1): 99-105. [CrossRef]

[24] Scheffler A, Rauwald HW, Kampa B, Mann U, Mohr FW, Dhein S. Olea europaea leaf extract exerts L-type Ca(2+) channel antagonistic effects. J Ethnopharmacol. 2008; 120(2): 233-240. [CrossRef]

[25] Carluccio MA, Siculella L, Ancora MA, Massaro M, Scoditti E, Storelli C, Visioli F, Distante A, De Caterina R. Olive oil and red wine antioxidant polyphenols inhibit endothelial activation: antiatherogenic properties of Mediterranean diet phytochemicals. Arterioscler Thromb Vasc Biol. 2003; 23(4): 622-629. [CrossRef]

[26] Dell'Agli M, Fagnani R, Mitro N, Scurati S, Masciadri M, Mussoni L, Galli GV, Bosisio E, Crestani M, De Fabiani E, Tremoli E, Caruso D. Minor components of olive oil modulate proatherogenic adhesion molecules involved in endothelial activation. J Agric Food Chem. 2006; 54(9): 3259-3264. [CrossRef]

[27] Elmazoglu Z, Göker B, Bek ZA, Aktekin CN, Bitik B, Karasu C. Standardized extract of Olea europaea leaves suppresses pro-inflammatory cytokines through regulating redox signaling pathways in human chondrocytes. Osteoarthritis and Cartilage. 2020; 28 (Suppl 1): S105-S106. [CrossRef]

[28] Shi C, Chen X, Liu Z, Meng R, Zhao X, Liu Z, Guo N. Oleuropein protects L-02 cells against $\mathrm{H}_{2} \mathrm{O}_{2}$-induced oxidative stress by increasing SOD1, GPx1 and CAT expression. Biomed Pharmacother. 2017; 85: 740-748. [CrossRef]

[29] Odiatou EM, Skaltsounis AL, Constantinou AI. Identification of the factors responsible for the in vitro pro-oxidant and cytotoxic activities of the olive polyphenols oleuropein and hydroxytyrosol. Cancer Lett. 2013; 330(1): 113-121. [CrossRef]

[30] Janiga I, Mocak J, Garaj I. Comparison of minimum detectable concentration with the IUPAC detection limit. Meas Sci Rev. 2008; 8(5): 108-110. [CrossRef]

[31] Singleton VL, Rossi JA. Colorimetry of total phenolics with phophormolybdic phosphotungstic acid reagents. Am J Enolvitic. 1965; 16: 144-158.

[32] Mosmann T. Rapid colorimetric assay for cellular growth and survival: application to proliferation and cytotoxicity assays. J Immunol Methods. 1983; 65(1-2): 55-63. [CrossRef]

[33] Waxman AB, Mahboubi K, Knickelbein RG, Mantell LL, Manzo N, Pober JS, Elias JA. Interleukin-11 and interleukin6 protect cultured human endothelial cells from $\mathrm{H}_{2} \mathrm{O}_{2}$-induced cell death. Am J Respir Cell Mol Biol. 2003; 29(4): 513522. [CrossRef]

[34] Rosenkranz AR, Schmaldienst S, Stuhlmeier KM, Chen W, Knapp W, Zlabinger GJ. Microplate assay for the detection of oxidative products using 2',7'-dichlorofluorescein-diacetate. J Immunol Methods. 1992; 156(1): 39-45. [CrossRef] 